\title{
Study on factors influencing caesarean section delivery in urban field practice area of Kamineni Institute of Medical Sciences, Narketpally, Nalgonda, India
}

\author{
Sarala Kumari Balmur'1, Visweswara Rao Guthi ${ }^{2 *}$
}

${ }^{1}$ Department of Obstetrics and Gynecology, ${ }^{2}$ Department of Community Medicine, Kamineni Institute of Medical Sciences, Narketpally, Nalgonda, Telangana, India

Received: 15 May 2017

Accepted: 10 June 2017

\section{*Correspondence:}

Dr. Visweswara Rao Guthi,

E-mail: vissumbbs@gmail.com

Copyright: () the author(s), publisher and licensee Medip Academy. This is an open-access article distributed under the terms of the Creative Commons Attribution Non-Commercial License, which permits unrestricted non-commercial use, distribution, and reproduction in any medium, provided the original work is properly cited.

\begin{abstract}
Background: Caesarean section is one of the most commonly performed major surgeries in obstetric practice intended to save the mother and child in turn reducing maternal and perinatal mortality. The steadily increasing global rate of caesarean section has become one of the most debated topics in maternity care. The objective of this study is to identify the factors influencing caesarean section delivery in the study area.

Methods: This is a community based cross sectional study conducted among 66 women who underwent caesarean section in urban slum of field practice area of KIMS Nalgonda from January 2017 to February 2017. Information regarding socio demographic factors, indication of caesarean section, maternal and neonatal outcome was recorded in pre-designed pretested questionnaire.

Results: The rate of caesarean section (CS) in this study was 55.9\%. The commonest indication for elective caesarean was previous caesarean section $(59.5 \%)$ and for emergence caesarean section the commonest indication was fetal distress (50\%). $47.6 \%$ in elective group and $62.5 \%$ in emergency underwent caesarean section in government hospitals, $52.38 \%$ in elective group and $37.5 \%$ in emergency underwent caesarean section in private nursing homes.

Conclusions: Elective caesarean sections are more common than emergency sections. Most of the caesarian sections were in the age group of 18-25 years, Hindus, BC community, house wives, who have studied up to intermediate and above, below poverty line group and in multigravida women. Common indication for elective CS was previous CS and for emergency CS was fetal distress.
\end{abstract}

Keywords: Caesarean section, Socio demographic factors, Urban slum

\section{INTRODUCTION}

Caesarean section is one of the most commonly performed major surgeries in obstetric practice intended to save the mother and child in turn reducing maternal and perinatal mortality. The steadily increasing global rate of caesarean section have become one of the most debated topics in maternity care as its prevalence has increased alarmingly in last few years. ${ }^{1,2}$ Prevalence of caesarean section in USA is $29.1 \%$ and in England $21.5 \% .^{3,4}$ WHO states that no additional health benefits are associated with a caesarean section rate above $15 \% .^{5}$

A study by ICMR in 33 tertiary care institutions noticed that the average caesarean section rate increased from $21.8 \%$ in $1993-94$ to $25.4 \%$ in $1997-98$. Causes of increasing trend in caesarean section is high education back ground of women, low tolerance for labour pains, 
economically sound state of family, presence of more private hospitals. WHO withdrew its previous recommendation of $15 \%$ caesarean section rate in June 2010, their official statement rate there is no empirical evidence for an optimum percentage. What matters most is that all women who need caesarean section receive them. ${ }^{6}$ The objective of this study was to identify the factors influencing caesarean section in the study area.

\section{METHODS}

This is a community based cross sectional study conducted among 66 women who underwent caesarean section in urban slum of field practice area of Kamineni Institute of Medical Sciences, Narketpally, Nalgonda from January 2017 to February 2017.

The study population included all women who underwent caesarean section in urban field practice area of Kamineni Institute of Medical Sciences in the calendar year 2016. Thus 66 women were enrolled. Information regarding socio demographic factors, indication of caesarean section, maternal and neonatal outcome was recorded in pre-designed pretested questionnaire. Data was entered in Microsoft excel analyzed.

\section{RESULTS}

Total number of deliveries that took place in this urban slum of field practice area of Kamineni Institute of Medical Sciences Nalgonda were 118 among them 52 were normal deliveries and 66 women delivered by caesarean section for various indications. The rate of caesarean section in this study was $55.9 \%$. Mean age in elective caesarean section was 23.35 years and in emergency group was 23.58 years.

Table 1: Distribution of cases according to type caesarean section.

\begin{tabular}{|lll|}
\hline Type of caesarean section & Number & $\%$ \\
\hline Elective & 42 & 63.64 \\
\hline Emergency & 24 & 36.36 \\
\hline Total & 66 & 100 \\
\hline
\end{tabular}

Table 1 shows elective caesarean sections (63.64\%) are more common than emergency sections $(36.36 \%)$. The commonest indication for elective caesarean section in our study is previous section which is 59.5\% and for emergency caesarean section the commonest indication was foetal distress $(50 \%)$.

Table 2: Distribution of cases according to socio demographic factors.

\begin{tabular}{|c|c|c|c|c|c|}
\hline Age & Elective CS & Percentage & Emergency CS & Percentage & P value \\
\hline $18-25$ years & 33 & 78.57 & 16 & 66.66 & \multirow{2}{*}{0.28} \\
\hline $26-35$ years & 9 & 21.43 & 8 & 33.34 & \\
\hline \multicolumn{6}{|l|}{ Religion } \\
\hline Hindu & 37 & 88.9 & 22 & 91.66 & \multirow{3}{*}{0.87} \\
\hline Muslims & 2 & 4.76 & 1 & 4.17 & \\
\hline Christian & 3 & 7.15 & 1 & 4.17 & \\
\hline \multicolumn{6}{|l|}{ Caste } \\
\hline $\mathrm{SC}$ & 7 & 16.66 & 1 & 4.16 & \multirow{3}{*}{0.32} \\
\hline $\mathrm{OC}$ & 6 & 14.28 & 4 & 16.67 & \\
\hline $\mathrm{BC}$ & 29 & 69.6 & 19 & 79.17 & \\
\hline \multicolumn{6}{|l|}{ Occupation } \\
\hline House wife & 14 & 33.33 & 4 & 16.66 & \multirow{3}{*}{0.23} \\
\hline Labour & 21 & 50 & 17 & 70.84 & \\
\hline Service & 7 & 16.67 & 3 & 12.50 & \\
\hline \multicolumn{6}{|l|}{ Education } \\
\hline Illiterate & 10 & 23.82 & 11 & 45.83 & \multirow{4}{*}{0.14} \\
\hline Primary & 2 & 4.76 & 0 & 0 & \\
\hline Secondary & 15 & 35.71 & 4 & 16.67 & \\
\hline Inter and above & 15 & 35.71 & 9 & 37.50 & \\
\hline \multicolumn{6}{|c|}{ Socioeconomic status } \\
\hline Above poverty line & 9 & 21.43 & 3 & 12.5 & \multirow{2}{*}{0.36} \\
\hline Below poverty line & 33 & 78.57 & 21 & 87.5 & \\
\hline \multicolumn{6}{|l|}{ Parity } \\
\hline Primi gravida & 11 & 26.19 & 15 & 62.5 & \multirow{2}{*}{0.003} \\
\hline Multi gravida & 31 & 73.82 & 9 & 37.5 & \\
\hline Total & 42 & 100 & 24 & 100 & \\
\hline
\end{tabular}


Table 2 shows that there were no caesarean sections in the age group below 18 years. Among 18-25 years $78.57 \%$ were in elective caesarean section group and $66.66 \%$ in emergency caesarean section. Among 26-35 years $21.42 \%$ were in elective caesarean section group and $33.33 \%$ in emergency group. None was there beyond
35 years of age. Among Hindus $88.9 \%$ deliveries were elective caesarean section and $91.66 \%$ in emergency group, among Muslims $4.76 \%$ in elective and $4.16 \%$ in emergency group, among Christians $7.14 \%$ in elective group and $4.16 \%$ in emergency group. Caste wise $16.66 \%$ in elective, $4.16 \%$ in emergency group belong to $\mathrm{SC}$, there were no ST candidates in present study.

Table 3: Distribution of cases according to indication maternal and neonatal outcome.

\begin{tabular}{|lllll|}
\hline Hospitals & Elective CS & Percentage & Emergency CS & Percentage \\
\hline Government & & & & 62.15 \\
\hline Private & 20 & 47.61 & 9 & 37.5 \\
\hline Indications for elective CS & 22 & 52.38 & & - \\
\hline Abnormal presentation & 7 & & - & - \\
\hline Previous CS & 25 & 16.66 & - & - \\
\hline Pre eclampsia and eclampsia & 5 & 59.52 & - & - \\
\hline CPD & 5 & 11.9 & - & \\
\hline total & 42 & 11.9 & 12 & 50 \\
\hline Indication for emergency CS & & 99.99 & 9 & 37.5 \\
\hline Foetal distress & - & & 2 & 8.33 \\
\hline Non progressive labour & - & - & 1 & 4.16 \\
\hline Premature ruptue of membranes & - & - & 24 & 99.99 \\
\hline Pre eclampsia and eclampsia & - & - & & \\
\hline Total & & - & & \\
\hline
\end{tabular}

Table 4 Distribution of cases according to maternal and neonatal outcome

\begin{tabular}{|c|c|c|c|c|}
\hline Maternal complications & Elective CS & $\%$ & Emergency CS & $\%$ \\
\hline Nil & 36 & 85.71 & 19 & 79.16 \\
\hline Infection & 2 & 4.76 & 1 & 4.16 \\
\hline PPH & 4 & 9.52 & 4 & 16.66 \\
\hline Total & 42 & 99.99 & 24 & 99.99 \\
\hline \multicolumn{5}{|l|}{ Neonatal outcome } \\
\hline Good & 33 & 78.57 & 17 & 70.83 \\
\hline Congenital anomalies & 4 & 9.52 & 0 & 0 \\
\hline Asphyxia & 3 & 7.14 & 1 & 4.16 \\
\hline NICU admission & 2 & 4.76 & 6 & 25 \\
\hline Total & 42 & 99.99 & 24 & 99.99 \\
\hline
\end{tabular}

$14.28 \%$ in elective group and $16.66 \%$ in emergency group belong to OC category, $69.4 \%$ in elective group and $79.16 \%$ in emergency group belongs to BC category. Occupation wise $33.33 \%$ in elective and $16.66 \%$ in emergency group were housewives, $50 \%$ in elective and $70.83 \%$ in emergency group were labourers. $16.66 \%$ in elective and $12.5 \%$ in emergency were in service. $23.8 \%$ in elective group and $45.83 \%$ in emergency group were illiterates, $4.76 \%$ in elective and none in emergency had primary education, $35.71 \%$ in elective and $16.66 \%$ in emergency had secondary education, $35.71 \%$ in elective and $37.5 \%$ in emergency had above inter education. $21.42 \%$ in elective group and $12.5 \%$ in emergency group belong above poverty line category. $78.57 \%$ in elective and 87.55 in emergency group belong below poverty line group. $26.19 \%$ in elective group and $62.5 \%$ in emergency were primigavidas.73.80\% in elective and $37.5 \%$ in emergency were multigravidas.

Table 3 shows distribution of cases according to place of delivery, indication for CS, maternal and neonatal outcome. $47.6 \%$ in elective group and $62.5 \%$ in emergency underwent caesarean section in government hospitals, $52.38 \%$ in elective group and $37.5 \%$ in emergency underwent caesarean section in private nursing homes. Indication for elective caesarean section, $16.66 \%$ were for abnormal presentation, $59.5 \%$ for previous caesarean section, $11.9 \%$ for Pre eclampsia and eclampsia and $11.9 \%$ for CPD. In emergency caesarean $50 \%$ were done for foetal distress, $37.5 \%$ for non- 
progressive labour, $8.3 \%$ foe premature rupture of membranes and $4.16 \%$ for Pre eclampsis and eclampsia.

Table 4 shows $4.76 \%$ in elective group and $4.16 \%$ in emergency group suffered from infection, $9.5 \%$ in elective group and $16.66 \%$ in emergency group had PPH. $78.5 \%$ in elective and $70.8 \%$ in emergency group neonatal outcome was good. Congenital anomalies were found in $9.52 \%$ in elective group and none were found in emergency group. Asphyxia for short period was observed in $7.14 \%$ in elective group and $4.16 \%$ in emergency group. NICU admissions were $4.76 \%$ in elective group and $25 \%$ in emergency group. PPH and NICU admissions were more in emergency caesarean sections. The commonest indication foe elective caesarean section was previous caesarean section $(59.5 \%)$ followed by abnormal presentation, PET and eclampsia, CPD.

\section{DISCUSSION}

In this study, there were 118 deliveries in the calendar of the year 2016, in the urban slum of field practice area of Kamineni institute of medical sciences. Among them 66 were caesarean sections giving a rate of $55.9 \%$ which is very high compared to many studies. Vermas et al reported a rate of $21.32 \% .^{7}$ There was no maternal deaths. There were no intraoperative complications.

There was more of elective caesarean section deliveries $(63.6 \%)$ compared to emergency caesarean section deliveries $(36.3 \%)$. This due to indications for elective caesarean being previous caesarean section. Majority women were in the age group between 18-25 years $(78.5 \%)$ in elective and $66.66 \%$ in emergency group, whereas Vermas et al study majority of the women were in $26-30$ years $(51 \%)$ in elective group and $21-25$ years $(49 \%)$ in emergency group. Primigravida constituted $73.8 \%$ in elective group and $37.5 \%$ in emergency group. In a study by Smith $\mathrm{S} 42.4 \%$ where pirmigravida in both elective and emergency group. In our study pimigravidas are more in emergency group $(62.5 \%){ }^{8}$

The commonest indication for elective caesarean section was previous caesarean section $(59.52 \%)$ followed by abnormal presentation $(10.66 \%)$, Pre eclampsia and eclampsia (11.9\%) and CPD (11.9\%). The commonest indication for emergency caesarean section was foetal distress $(50 \%)$ followed by non-progressive labour $(37.5 \%)$, premature rupture of membranes $(8.3 \%)$, Pre eclampsia and eclampsia $(4.16 \%)$. The overall rates in all groups were higher in this study. This study is similar to DENSIC.WHO reported $61.5 \%$ cases of previous caesarean sections as an indication for elective caesarean sections and non-progressive labour of $41.5 \%$ in emergency caesarean section group. ${ }^{6,9}$ This study was conducted in the year 2008. In present study caesarean section rate is very high, the reason being, the women who underwent caesarean for the first time were not in favor of vaginal delivery due to unpredictable course of VBAC.
VBAC (vaginal birth after caesarean section) rates raised in 1980 and $1990 .{ }^{10}$ A major turning point occurred in 1996 when a well published NOVA SCOTIA study reported that vaginal after previous caesarean section resulted in more maternal complications than the repeat caesarean sections. ${ }^{11}$ As a result the rate at which VBAC was attempted fell from $28.3 \%$ in 1996 to less than $10 \%$ in $2010 .^{10,11}$

This study was conducted in urban slums where caesarean sections were performed in district government hospitals and private nursing homes where it is difficult to monitor VBAC compared to teaching hospitals where enough number of skilled persons will be present to monitor woman in labour.

\section{CONCLUSION}

This study concluded that elective caesarean sections were more common than emergency sections. Most of the caesarian sections were in the age group of 18-25 years, Hindus, BC community, house wives, who have studied up to inter and above, below poverty line group and in multi garvida women. Common indication for elective CS was previous CS and for emergency CS was fetal distress. Common complication in both groups was PPH. The increase in caesarean section rate causes burden to general health system, also strain on family members and may complicate maternal and child health. Hence caution should be exercised in decision making to perform caesarean section delivery especially in primigravida. Government should develop better health care infrastructure to reduce increasing trend in caesarean section deliveries.

\section{Funding: No funding sources}

Conflict of interest: None declared

Ethical approval: The study was approved by the Institutional Ethics Committee

\section{REFERENCES}

1. Tampakoudis P, Assimakopoulos E, Grimbizis G, Zafrakas M, Tampakoudis G, Mantalenakis S et al. Cesarean section rates and indications in Greece: data from a 24-year period in a teaching hospital. Clin Experimen Obstet Gynecol. 2004;31(4):289-92.

2. Lee SI, Khang YH, Lee MS. Women's attitudes toward mode of delivery in South Korea: a society with high cesarean section rates. Birth. 2004;31(2):108-16.

3. Hamilton be, Ventura SJ, Martin JA, Sulton PD, Menacker F. Preliminary births for 2004. Natl Vital Stat Rep. 2005;54(8):1-17.

4. Thomas Jothy $\mathrm{S}$. The national sentinel caesarean section and it report. RCOG press. 2001. Available at https://www.rcog.org.uk/global assets/documents/guidelines/researchaudit/nscs_audit.pdf. 
5. Belizan JM, Althabe F, Barros FC, Alexander S. Rates and implications of caesarean sections in Latin America. BMJ. 1999;319(7222):1397-1402.

6. Focus on: Caesarean section-NHS institute for innovation and improvement institute. 2009. Available at https://www.qualitasconsortium.com/index.cfm/refer ence-material/delivering-value-quality/focus-oncsection/

7. Verma S, Saini J, Sehra R, Nagaraj N. A clinical study of rate and indications of cesarean section, maternal and fetal outcomes at tertiary care center in north western Rajasthan. Int $\mathrm{J}$ Reprod Contracept Obstet Gynecol. 2016;5(8):2791-4.

8. DENISC. Fear of pain causes a bit rise in caesarean section. 26.October 2008.

9. Gregory KD, Fridman M, Korst L. Trends and patterns of vaginal birth after caesarean availability in the United States. Semi perinatal. 2010;34(4)23743.

10. Mc Mahon, Luther ER, Bowes Wa, Olshan Af. Comparision of a trial of labour with an elective secon caesarean section. $\mathrm{N}$ Engl J Med. 1996;335:689-95.

11. Cunningham FG, Bangdiwala S, Brown SS, Dean TM, Frederiksen M, Hogue CJ et al. National Institutes of health consensus development conferenced statement: vaginal birth after caesarean: new insights. Obstet Gynecol. 2010;115:1279-95.

Cite this article as: Balmur SK, Guthi VR. Study on factors influencing caesarean section delivery in urban field practice area of Kamineni Institute of Medical Sciences, Narketpally, Nalgonda, India. Int J Reprod Contracept Obstet Gynecol 2017;6:3129-33. 